\title{
Therapeutic Potential of Polyphenols-Loaded Polymeric Nanoparticles in Cardiovascular System
}

\author{
Olga Pechanova* * Ezgi Dayar $₫$ and Martina Cebova \\ Institute of Normal and Pathological Physiology, Centre of Experimental Medicine, Slovak Academy of Sciences, \\ 81371 Bratislava, Slovakia; ezgi.dayar@savba.sk (E.D.); martina.cebova@savba.sk (M.C.) \\ * Correspondence: olga.pechanova@savba.sk; Tel.: +421-911-938-910 \\ Academic Editors: Iwona Cicha and Alejandro Baeza \\ check for \\ updates
}

Received: 31 May 2020; Accepted: 17 July 2020; Published: 22 July 2020

\begin{abstract}
Numerous studies document an increased production of reactive oxygen species (ROS) with a subsequent decrease in nitric oxide (NO) bioavailability in different cardiovascular diseases, including hypertension, atherosclerosis, and heart failure. Many natural polyphenols have been demonstrated to decrease ROS generation and/or to induce the endogenous antioxidant enzymatic defense system. Moreover, different polyphenolic compounds have the ability to increase the activity/expression of endothelial nitric oxide synthase (eNOS) with a subsequent enhancement of NO generation. However, as a result of low absorption and bioavailability of natural polyphenols, the beneficial effects of these substances are very limited. Recent progress in delivering polyphenols to the targeted tissues revealed new possibilities for the use of polymeric nanoparticles in increasing the efficiency and reducing the degradability of natural polyphenols. This review focuses on the effects of different natural polyphenolic substances, especially resveratrol, quercetin, curcumin, and cherry extracts, and their ability to bind to polymeric nanoparticles, and summarizes the effects of polyphenol-loaded nanoparticles, mainly in the cardiovascular system.
\end{abstract}

Keywords: hypertension; atherosclerosis; heart failure; ROS; nitric oxide; polymeric nanoparticles; resveratrol; quercetin; curcumin; cherry extracts

\section{Introduction}

Scientific research in recent years has placed significant focus on exploring the beneficial effects of natural polyphenols in the prevention and treatment of cardiovascular and neurodegenerative diseases and, in particular, cancer [1-3]. Polyphenols belong to a group of powerful antioxidants that supplement and enhance the function of endogenous antioxidants and enzymes involved in defensive action against the increased oxidative load caused by overproduction of reactive oxygen species (ROS) [3,4]. Moreover, many polyphenolic compounds have been shown to increase the activity/expression of endothelial nitric oxide synthase (eNOS) with subsequent enhanced nitric oxide generation $[5,6]$.

Serious findings suggest that overproduction of ROS and oxidative stress accompany different cardiovascular diseases, including hypertension, atherosclerosis, and heart failure (for a review, see Reference [7]). Thus, reducing oxidative stress may protect and improve cardiovascular and metabolic functions through different cellular and molecular mechanisms. A number of articles assert that increased superoxide generation with subsequent decreased nitric oxide (NO) bioavailability is the most important cause of endothelial damage and impaired endothelium-dependent relaxation, which leads to hypertension, atherosclerosis, and heart failure $[8,9]$. 


\section{ROS/NO Disbalance in Cardiovascular Diseases}

\subsection{Hypertension}

Nicotinamide adenine dinucleotide phosphate (NADPH) oxidase, namely, Nox1, Nox2, Nox4, and Nox5 isoforms, have been identified as the main sources of ROS in vascular cells during hypertensive conditions [9-11]. Both pharmacological inhibition and genetic deletion of NADPH oxidase lead to lowering blood pressure in the animal models of hypertension [7,11,12]. Nox5 seems to play an important role in human health, and disease in particular [10]. In addition, further potential sources of enzymatic ROS production, e.g., xanthine oxidase, mitochondrial electron transport chain, lipoxygenase, cyclooxygenase, peroxidases, hem oxygenases, and uncoupled endothelial NO synthase (NOS), have been documented to significantly contribute to the oxidative stress in hypertension $[7,9,13]$. Superoxide-mediated oxidation of $\mathrm{BH} 4$, and deficiency of the substrates L-arginine and S-glutathionylation, have been described as the main molecular mechanisms of NOS uncoupling [14-16]. Similarly, decreased activity of antioxidant enzymes like superoxide dismutase (SOD), catalase, glutathione peroxidase, or glutathione reductase importantly contributes to oxidative stress during increased blood pressure [7,17].

ROS may also activate proinflammatory nuclear factor kappaB (NF- $\kappa \mathrm{B})$-dependent pathways and increase levels of cytokines, such as interleukin 1 (IL-1) and tumor necrosis factor (TNF)- $\alpha$, with subsequent phosphorylation of tyrosine kinases and inhibition of eNOS activity (for a review, see Reference [18]). On the other hand, activation/delivery of eNOS to different hypertensive modes may prevent or reduce increased blood pressure [9,19]. Moreover, NO has been shown to antagonize the vasoconstrictor and proliferative effects of angiotensin II (Ang II), while it decreases sodium excretion and the expression of the angiotensin-converting enzyme (ACE) and angiotensin AT1 receptor [20]. Recently, platelet-derived NO was demonstrated to play an important role in the regulation of platelet function and the adhesive process in hypertensive patients [21].

\subsection{Atherosclerosis}

The atherosclerotic process in the arterial wall is characterized by ROS-mediated oxidation of low-density lipoproteins (LDL) cholesterol to oxidized (ox) LDL cholesterol [22,23]. Products of lipid peroxidation, such as malondialdehyde, oxidized phospholipid, and 4-hydroxynonenal, belong to highly reactive species and lead to the generation of oxidation-specific epitopes (OSEs) [24]. ROS may potentiate OSE sensing by increased expression of endothelial TLR2, TLR4, and lectin-like oxidized LDL receptor-1 [24,25]. Damage to the arterial wall is characterized by excessive fibrosis of the intima and fatty plaque formation due to LDL/oxLDL cholesterol accumulation, proliferation of smooth muscle cells, and infiltration and/or migration of monocytes, T cells, and platelets. Penetration of the cells into the vascular wall is conditioned by the expression of leukocyte and chemokine adhesion molecules, in which the transcription is performed by NF- $\mathrm{kB}$. Proinflammatory molecules, such as interleukin 6 (IL-6), interleukin 18 (IL-18), and TNF- $\alpha$ cytokines, adhesion molecules, matrix metalloproteinases (MMPs), and C-reactive protein (CRP) produced by monocytes, macrophages, and/or adipose tissue further potentiate microinflammation and the oxidative load [26,27].

Endothelial NO has the opposite role in this process, decreasing expression of the adhesion molecule and inhibiting endothelial-leukocyte interaction and cytokine-induced NF- $\mathrm{B}$ activation [28,29]. Activation/targeted delivery of endothelial NOS and SOD to endothelial cells decreases leukocyte adherence, inhibits NF- $\mathrm{KB}$ activation, and reduces adhesion molecule expressions in different in vitro and in vivo experiments [30,31]. Similarly, platelet-derived NO may significantly contribute to the reduction of the adhesive process [21].

\subsection{Heart Failure}

Increased NADPH oxidase activity has also been demonstrated during conditions leading to heart failure. The most common causes of increased NADPH oxidase activity include enhanced production 
of Ang II, endothelin-1, or TNF- $\alpha$, and increased mechanical stretch [32-34]. Nox2 and Nox4 have been identified as the main isoforms in cardiomyocytes in heart failure. Nox4, localized primarily within the mitochondria, seems to be mainly responsible for increased ROS generation [34]; however, diaphragms from patients with heart failure have shown Nox2 expression and p47phox phosphorylation highly associated with elevated protein oxidation [35]. Moreover, aldosterone-dependent activation of Nox2 significantly contributes to the profibrotic effect of Ang II in the heart [33]. Deficiency of NADPH oxidase has been shown to protect the heart from left ventricular remodeling and dysfunction after myocardial infarction [36]. Uncoupled eNOS has also been shown to further increase ROS production, leading to left ventricular remodeling, left ventricular dilatation, and contractile dysfunction [37].

In contrast, the functional dimer of eNOS with normal NO production may improve contractile function and decrease interstitial fibrosis in the impaired myocardium [38,39]. Indeed, organic nitrates, including nitroglycerin (GTN) and isosorbide mono (ISMN) and dinitrate (ISDN), have been used in cardiovascular medicine for 150 years. These drugs reliably ensure vasodilator activity necessary for the treatment of coronary artery disease and heart failure [39]. It was also demonstrated that nebivolol, belonging to the third generation of $\beta$-blockers with NO-dependent properties, and the NO donor LA-419 may improve left ventricular function and reduce left ventricular hypertrophy at doses that do not affect arterial blood pressure $[9,39,40]$.

\section{Effects of Natural Polyphenolic Substances on ROS/NO Disbalance}

Natural polyphenols generally have low bioavailability and different kinetic restrictions; thus, the direct free radical scavenger activity of these substances is very limited. There are a number of studies documenting the rather indirect antioxidant effect of polyphenols. Many polyphenols have been demonstrated to modify expression of different genes and to induce the endogenous antioxidant enzymatic defense system [41-43] (Figure 1). For example, treatment with chlorogenic acid, a dietary polyphenol, has been shown to decrease NADPH oxidase activity in spontaneously hypertensive rats (SHR) [44] and to prevent decreased activity of SOD, catalase, glutathione peroxidase, and glutathione-S-transferase in isoproterenol-induced myocardial oxidative stress in the rat myocardium [45]. Similarly, the beneficial cardioprotective effect of malvidin by restoring catalase, SOD, and glutathione peroxidase has been documented in a similar model of myocardial infarction [46]. On the other hand, kaempferol improved cardiac function via the activation of extracellular signal-regulated protein kinases 1 and 2 (ERK1/2) and the inhibition of p38 and C-jun $N$-terminal kinase (p38/JNK)/TNF- $\alpha / \mathrm{NF}-\mathrm{kB} / \mathrm{p} 65$ pathways in the model of myocardial ischemia-reperfusion injury [47]. Another well-known polyphenol, quercetin, has the ability to attenuate postconditioning myocardial ischemia/reperfusion injury in rats through the activation of the phosphatidylinositol 3-kinase (PI3K)/Akt pathway [48].

Resveratrol has a variety of cardiovascular-beneficial effects. In SHR, it has been shown to decrease both NADPH oxidase activity and overexpression of Nox2, Nox4, and p47phox [49]. It has been identified as a direct and indirect sirtuin 1 (SIRT1) activator [50,51] with an increasing effect on SIRT1 expression as well [52]. Resveratrol has been shown to activate nuclear factor erythroid 2-related factor (Nrf2) indirectly [53] and upregulate miRNA-21, thus exerting cardioprotective effects in cardiac remodeling and apoptosis [54]. Moreover, it has been shown to activate eNOS by stimulating the membrane estrogen receptor [55]. Specifically, a subpopulation of estrogen receptor (ER) $\alpha$ activated by resveratrol is bound with caveolae in the endothelial membrane and coupled to the eNOS through a G protein [56]. The diarylheptanoid, curcumin, also has important vascular protective effects. Curcumin treatment significantly delayed the onset of stroke and increased the survival of stroke-prone spontaneously hypertensive rats independently of blood pressure reduction. Upregulation of the NO pathway has been identified as a mechanism responsible for this preventive process [57]. Moreover, curcumin reduces NF- $\mathrm{kB}$, affecting gene regulation, and decreases the $\mathrm{TNF} \alpha$-induced expression of intercellular adhesion molecule-1 (ICAM-1), monocyte chemoattractant protein-1 (MCP-1), and IL-8 mRNA, characteristic of the atherosclerosis process [58]. Similarly, extracts 
from different cherries have been documented to be capable of favorable interactions with the risk factors of atherosclerosis. Besides their positive effects on the lipid spectrum and glycemia, reduction of ROS and improvement of endothelial dysfunction (Figure 1) have been demonstrated in both in vitro and in vivo experiments $[59,60]$. Recently, a new inverse molecular docking approach was used to identify potential human protein targets of curcumin and resveratrol, which could provide further insights into molecular mechanisms of antioxidant and anti-inflammatory actions of polyphenolic compounds $[61,62]$.

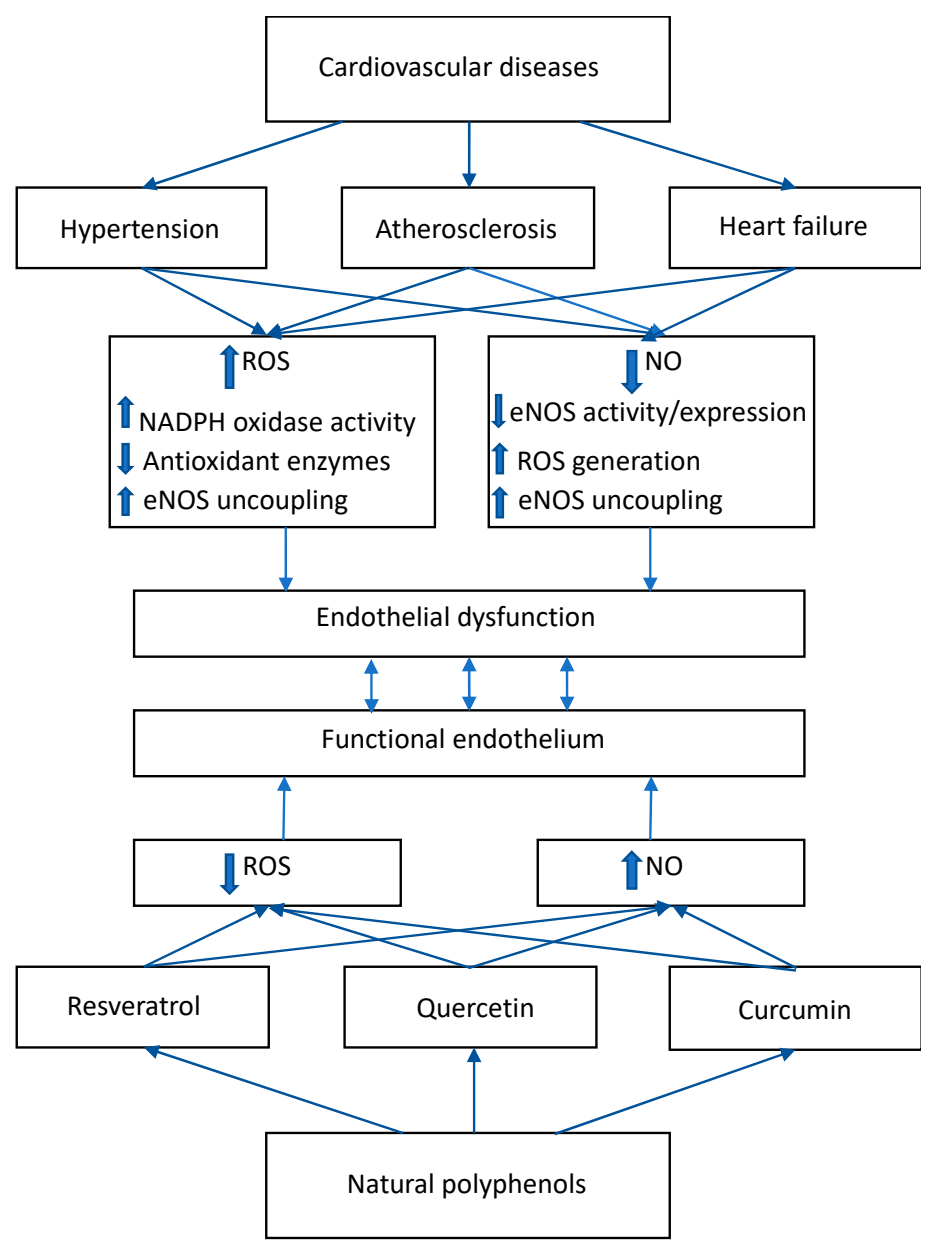

Figure 1. Cardiovascular diseases, including hypertension, atherosclerosis, and heart failure are accompanied by increased production of reactive oxygen species (ROS), also via enhanced nicotinamide adenine dinucleotide phosphate (NADPH) oxidase activity, with subsequent decreased nitric oxide (NO) generation, leading to endothelial dysfunction. Many natural polyphenols like resveratrol, quercetin, or curcumin are able to fight endothelial dysfunction by their ability to decrease ROS generation, induce the endogenous antioxidant enzymatic defense system, and increase activity/expression of endothelial NO synthase (eNOS).

Thus, the effects of polyphenolic compounds and their molecular actions in the cardiovascular system are different depending on both the type of polyphenol and respective cardiovascular disease. The absorption and bioavailability of natural polyphenols are, however, too low, and can be a serious obstacle for the beneficial actions of these substances. To remedy the low bioavailability, low solubility, and rapid degradability of polyphenols, different approaches have been developed with the aim to transport the respective polyphenolic substance throughout the gastrointestinal tract and deliver it to the targeted tissue. Recent progress in delivering polyphenols to the targeted tissues is characterized on three carrier levels, namely liposomes, microemulsion, and nanoparticles (for a 
review, see Reference [42]). Among them, biopolymeric nanoparticles represent a promising strategy for the protection and effective targeted delivery of natural polyphenolic substances.

\section{Polymeric Nanoparticles}

Recently, the use of polymeric nanoparticles has been based on nonbiodegradable polymers, such as polyacrylamide, polystyrene, and poly (methyl) methacrylate [63]. For such particles, inflammatory responses and chronic toxicity were observed, and therefore, research has focused on biodegradable polymeric nanoparticles with reduced toxicity, higher biocompatibility, and a better ability to regulate drug release kinetic patterns. With the exception of natural polymers like chitosan, albumin, alginate, and gelatine, the synthetic polymers mainly include poly (lactide) (PLA), poly (lactide-co-glycolide) copolymers (PLGA), poly ( $\varepsilon$-caprolactone) (PCL), and poly (amino acids) [64-67]. These biodegradable synthetic polymers should fulfil two major requirements: performance and safety. They have to have the maximum biocompatibility to have a therapeutic effect, and biodegradation in a timeframe compatible with the healing of the target system or tissue. At the same time, they should be safe, which means not inducing in vivo toxicity and not promoting an inflammatory response in the immunological system [68].

Firstly, polyethylene glycol (PEG)-coated synthetic copolymers conjugated with active mediators have been shown to yield drug delivery systems with positive properties $[69,70]$. PEG coatings form a hydrated ring which prevents protein interactions and reduces opsonization, resulting in an increased circulation time and lower activation of the immune system [71]. Furthermore, a conjugation of glycoprotein $\mathrm{Ib}(\mathrm{GPIb})$ to PLGA nanoparticles has been shown to increase nanoparticle adhesion to the targeted surface, cellular uptake of nanoparticles, and controlled release of the active substances (for a review, see References [72,73]). PLA is relatively hydrophobic, which allows it to be used for implants like stents, screws for bone fixations, but also for drug delivery systems [74]. Polymeric nanoparticles have been reported to cross the intestinal barrier after oral administration and therefore, it is effectively used for oral drug delivery. It is generally accepted that the cells predominantly involved in the capture of nanoparticles administered intravenously are the macrophages of liver and spleen and circulating monocytes. The polymeric nanoparticles, along with toxins and unmetabolized nutrients, are passed through the kidney and taken up by the glomerular or peritubular capillaries, and eventually eliminated from the body by renal clearance [75].

Nowadays, targeted nanoparticle delivery systems in the field of cardiovascular disease are under intensive investigation. Minimizing the side effects while maximizing the drug effectiveness by targeted delivery poses a challenge not only in atherosclerosis, but also in hypertension, myocardial infarction, and heart failure (for a review, see References [72,73]). First, a liposome drug delivery system has been proven to be a successful option for the treatment of angina pectoris. Encapsulated amiodarone, an anti-arrhythmic drug, in conventional liposomes demonstrated a reduced morality rate due to arrhythmia and negative hemodynamic changes in rat models of cardiac ischemic/reperfusion procedure [76]. Later, treatment of aliskiren (a renin inhibitor)-loaded PLA nanoparticle decreased the blood pressure of SHR much more significantly than the powdered form [77]. Similarly, nanostructured lipid carriers and solid lipid nanoparticles improved the oral bioavailability of a calcium channel blocker, nisoldipine [78]. PLGA and PCL seem to be effective delivery systems for nifedipine and felodipine since they significantly reduced blood pressure in hypertensive rats [79,80]. Innovative NO-releasing polymeric nanomaterials are among the new potential solutions in the development of qualitatively new antihypertensive drugs [81]. Osako et al. demonstrated that the PEG-PLGA copolymer is able to deliver a NF-KB decoy oligodeoxynucleotide, which is directed against the NF- $\kappa B$ binding site in the promoter region [82]. This copolymer has been demonstrated to prevent monocrotaline-induced NF- $\mathrm{KB}$ activation in a rat model of monocrotaline-induced pulmonary arterial hypertension [83].

Still, the key problem with using nanoparticles is their toxicity. The small size and large surface area to volume ratio makes them very reactive. Nanoparticles may even generate ROS and other 
free radicals, resulting in an increased oxidative load and inflammation [84]. Recently, natural polyphenols-loaded nanoparticles have been the focus of interest thanks to their antioxidant properties, which additionally may exceed the prooxidant effects of some nanoparticles. Among them, resveratrol, quercetin, curcumin, and cherry extracts are the most frequently studied.

\section{Therapeutic Effects of Polyphenols-Loaded Polymeric Nanoparticles}

\subsection{Effects of Resveratrol-Loaded Nanoparticles}

Resveratrol (3,5,4'-trihydroxystilbene) belongs to non-flavonoid polyphenolic compounds, specifically, to the stilbenoid group $[85,86]$. Resveratrol has two structural isoforms-cis and trans. Trans-resveratrol is known as the most abundant and active form of resveratrol [86,87]. This, a natural plant-derived polyphenol, is contained mainly in red grapes and wine [87], berries, peanuts, and soy $[88,89]$.

Preclinical studies have demonstrated that resveratrol has beneficial and protective effects on cardiovascular diseases, but also on diabetes, obesity, cancer, and neurodegenerative diseases. As a result of its pharmacological activities, resveratrol is classified as an antioxidant with anti-inflammatory, anti-carcinogenic, anti-aging, and cardioprotective properties [86,88]. Resveratrol has been shown to decrease the oxidative load by affecting antioxidant enzymes such as SOD, catalase, glutathione reductase, glutathione peroxidase, glutathione transferase, and oxidoreductases. Moreover, it increases eNOS production, inhibits lipid peroxidation $[86,90]$, mitogen-activated protein (MAP) kinases and iNOS activities [91], and has anti-inflammatory effects through the downregulation of proinflammatory mediators like COX-1 and COX-2 [92]. Increased eNOS activity/expression is the main protective effect of resveratrol against vascular damage in cardiovascular diseases. Moreover, in endothelial cells, iNOS expression is regulated by NF- $\mathrm{kB}$, which is inhibited by resveratrol [93]. Furthermore, resveratrol can also protect the cardiovascular system by modulating lipoprotein metabolism, inhibiting platelet aggregation [94,95], regulating vascular smooth muscle cell proliferation [91], inhibiting TNF- $\alpha$ [96], and upregulating tumor suppressor $\mathrm{p} 53$ [86].

The limitations associated with the pharmacological use of this polyphenol are poor water solubility, the short biological half-life, chemical instability, and rapid metabolism [86,97]. Thus, nanoparticle delivery systems represent an ideal way to transport resveratrol to target tissues and ensure sufficient bioavailability [86,98]. Resveratrol-loaded polymeric nanoparticles are no bigger than $100 \mathrm{~nm}$, so they can easily pass through the membrane and be internalized by cells. Resveratrol-loaded polymeric nanoparticles provide controlled drug release, increased drug solubility, drug targeting, and drug protection from degradation [86,89]. In the study by Singh and Pai [99], resveratrol-loaded PLGA nanoparticles had better oral bioavailability and absorptivity in rats in comparison with the pure drug [99]. Similarly, Siu et al. [100] documented that resveratrol-loaded galactosylated PLGA nanoparticles had better bioavailability and in vitro anti-inflammatory activity in rats and lipopolysaccharides-induced macrophage cell line RAW 264.7 cells, respectively [100]. Using carboxymethyl chitosan to prepare resveratrol-loaded nanoparticles provoked improvements in resveratrol antioxidant activity and bioavailability after oral administration in rats. Compared to the pure drug, resveratrol-loaded nanoparticles exhibited increased in vivo absorption, prolonged duration of action, and increased relative bioavailability by 3.5 times [101]. Oral administration of resveratrol loaded into $\mathrm{N}$-trimethyl chitosan conjugated with palmitic acid nanoparticles in $\mathrm{Balb} / \mathrm{c}$ mice provided a 3.8-fold increase in resveratrol bioavailability compared to the pure drug. This increase was attributed to the muco-adhesive and high absorption effects of the polymeric nanoparticles, as well as to the ability to prevent resveratrol degradation [89]. Cheng et al. [102] reported that dual-shell polymeric nanoparticles, multistage continuous targeted drug delivery carrier (MCTD)-NPs, which utilize a multistage continuous targeted strategy to deliver ROS scavengers specifically to the mitochondria of ischemic cardiomyocytes, increased the distribution of resveratrol in the ischemic myocardium and reduced infarct size in myocardial ischemia/reperfusion injury in rats [102]. Hardy et al. [103] used 
resveratrol-loaded multifunctional poly (glycidyl methacrylate) (PGMA) nanoparticles to study the effect in Langendorff I/R heart preparation. They reported that exposure of hearts to resveratrol-loaded nanoparticles was able to delay the release of creatine kinase and lactate dehydrogenase, the markers of an injured myocardium [103], (Table 1). Thus, resveratrol-loaded nanoparticles represent a promising tool for supportive treatment in cardiovascular diseases.

\subsection{Effects of Quercetin-Loaded Nanoparticles}

Quercetin (3,3', $4^{\prime}, 5,7$-pentahydroxyflavone), a powerful antioxidant, belongs to the flavonoid family, and it is generally present as quercetin glycoside, especially in plants [104-106]. Quercetin is bound to mono- or oligo-saccharides through the glycosidic bonds with the $3^{\prime}$ hydroxyl group on the oxygen-containing ring [106]. Quercetin is widely contained in grapes, berries, apples, cherries, citrus fruit, red wine, black tea, onions, and tomatoes. Concentrations of quercetin may vary depending on the plant or even on the parts of the same plant [107]. Like other polyphenols, quercetin has limited water solubility. The bioavailability of the water-soluble derivative of quercetin is only $20 \%$ [108]. However, quercetin glycoside has a higher bioavailability than quercetin rhamnoside or quercetin galactoside [107].

Quercetin has important cardio-protective effects, including antioxidant, anti-inflammatory, anti-atherosclerotic, and anti-hypertensive effects. It also has preventive effects in dyslipidemia, endothelial dysfunction, and platelet aggregation [109]. Quercetin exerts its anti-inflammatory effects by inhibiting cyclooxygenase and lipoxygenase and decreasing prostaglandins and C-reactive proteins $[110,111]$. In diabetic rats, quercetin has been shown to improve dyslipidemia, decrease serum glucose levels, and reduce oxidative stress [112] by scavenging ROS and modulating antioxidant enzymes [113]. In spontaneously hypertensive rats, quercetin lowered blood pressure [114], reduced transcription of NF-kB [115], and decreased IL-6, IL-1B, and TNF- $\alpha$ [116]. Dietary quercetin may modulate blood NO concentrations and inhibit NADPH oxidase activity [117].

The use of quercetin as a therapeutic target is, however, limited considering its poor aqueous solubility, instability in the physiological medium, and low bioavailability $[107,118]$. Therefore, polymeric nanoparticles are a good tool to increase bioavailability and reduce degradation of this flavonoid. Quercetin-loaded PLA nanoencapsulation demonstrated a higher water solubility and sustained release of the drug, leading to better bioavailability and stability of quercetin. On the other hand, the antioxidant capacities of the PLA-encapsulated quercetin and pure quercetin were almost the same [119]. Comparison of quercetin and catechin-loaded PLGA nanoparticles showed that quercetin was more slowly released from PLGA, probably due to the carbonyl and carboxyl interactions of the polymer and flavonoid molecules. Moreover, quercetin showed a higher radical scavenging activity compared to catechin [120]. Ghosh et al. [121] suggested that oral treatment with quercetin-loaded PLGA might play a protective role against oxidative damage in ischemia reperfusion induced in young and aged rats [121]. Wang et al. [122] layered a bioactive polymer (PLGA layers) onto superparamagnetic SiN to control the medication discharge profile. The PLGA layer on the outside of SiN can act as a gate-keeping layer to direct the medication discharge from SiN. They demonstrated that SiN@QC-PLGA nanobio-composite properties improve the practical similitude to the local myocardium, permitting cell enlistment, attachment, expansion, and articulation of heart proteins, which can be utilized in anticipation of atherosclerosis and other cardiovascular diseases [122] (Table 1). In addition, a novel system of polymeric PLGA nanoparticles loaded with quercetin and fabricated via the electrohydrodynamic atomization process may have great potential in the prevention of atherosclerosis and other relative cardiovascular diseases [118].

\subsection{Effects of Curcumin-Loaded Nanoparticles}

Curcumin (1,7-bis(4-hydroxy-3-methoxyphenyl)-1,6-heptadiene-3,5-dione), also called diferuloylmethane, is a polyphenolic compound contained in turmeric of the ginger family $[123,124]$. It is responsible for the intense yellow turmeric color. The rhizome of turmeric contains between 
$1.5 \%$ and $3 \%$ of curcumin [125]. The chemical structure of curcumin is composed of two aromatic ring systems including o-methoxy phenolic groups connected by $\alpha, \beta$-unsaturated $\beta$-diketone moiety. Curcumin displays enolic and diketonic forms due to tautomerism between enol and keto structures $[126,127]$.

Curcumin exhibits various beneficial physiological activities, including antioxidant, anti-inflammatory, and anti-proliferative effects. As a result of these therapeutic properties, curcumin has been shown to protect the heart against the development of cardiac hypertrophy, cardiotoxicity, and heart failure. It has beneficial effects in the atherosclerotic process and in diabetic cardiovascular complications [128]. Curcumin may improve oxidative stress, mitochondrial dysfunction, and inflammation through regulating various cell signaling pathways, including cytokines, chemokines, and growth factors and their receptors [123,129]. Curcumin exerts its anti-inflammatory effects via downregulation of NF- $\mathrm{kB}$, resulting in decreased expression of TNF- $\alpha$, IL-1, and IL6. Furthermore, curcumin inhibits the mitogen-activated protein kinase (MAPK) pathways [130] and activates lipoprotein lipase, peroxisome proliferator-activated receptor-gamma (PPAR-gamma), and PPAR-alpha [131,132]. The anti-proliferative effect of curcumin is supposed to be associated with its ability to induce heme-oxygenase- 1 expression in vascular endothelial cells, vascular smooth muscle cells, and human aortic smooth muscle cells $[133,134]$. In atherosclerotic conditions, curcumin has been shown to reduce the serum levels of triglycerides, total cholesterol, LDL-cholesterol, and free fatty acids [135]. Curcumin can also prevent the activation of 3-hydroxy-3-methylglutaryl-coenzyme a reductase (HMG-CoA) via a transcriptional mechanism [136].

Like other natural polyphenolic compounds, clinical use of curcumin is limited because of its low bioavailability, poor absorption, and rapid metabolism [128]. Only $30-40 \%$ of the orally administered drug can be absorbed and most of the ingested curcumin is excreted in feces, unchanged. The absorbed curcumin is rapidly metabolized and only less than $0.02 \%$ of the metabolites are recovered from the liver, kidney, and body fat $[137,138]$. Several preclinical and clinical studies have proposed that the route of curcumin administration is an important factor in terms of its serum and tissue levels [138]. Curcumin-loaded polymer nanoparticle systems are therefore intensively studied $[139,140]$.

The studies are focused on improving the solubility of the hydrophobic drug in the water, optimizing its stability, enhancing the pharmacokinetics, designing controlled release, preventing the drug from degradation, and targeting the organs. Using curcumin-loaded PLA-PEG copolymer nanoparticles, El-Naggar et al. [141] demonstrated that curcumin-loaded nanoparticles had better anti-inflammatory and antioxidant effects in a streptozotocin-induced diabetes model than pure curcumin [141]. In a similar model, curcumin-loaded chitosan nanoparticles promoted diabetic wound healing [142]. Carlson et al. [143] studied the cardio-protective effects of a combination of curcumin and resveratrol co-loaded into polymeric micellar in a cell model of doxorubicin-induced cardiotoxicity. The combination has been shown to markedly reduce apoptosis and ROS formation in the above cell model [143]. Similarly, curcumin-loaded copolymer PEG-Poly (ethylene glycol) methyl ether-block-poly (D, L lactide)-block-decane strongly inhibited apoptosis, lipid peroxidation, and production of NADPH-derived superoxides induced by exposure of cardiomyocytes to palmitate [144]. Curcumin-loaded to the same copolymer has been demonstrated to activate the AMP-activated protein kinase (AMPK)/mammalian target of the rapamycin complex-1/p-p70 ribosomal protein S6 kinase signaling pathway and regulate the expression of downstream proteins [145]. In a study by Nabofa et al. [146], the formulated curcumin-nisin-based PLA nanoparticles provided a significant level of cardio-protection in a guinea pig myocardial infarction model [146]. Curcumin encapsulated in carboxymethyl chitosan nanoparticles conjugated to a myocyte-specific homing peptide and successfully delivered to pathological myocardium was able to reduce cardiac hypertrophy and apoptosis in a rat model [147], and most importantly, in a double-blind randomized placebo-controlled clinical trial, nanocurcumin significantly decreased the levels of TNF- $\alpha$, high-sensitivity C-reactive protein (hs-CRP), and IL-6 compared to placebo [148] (Table 1). Thus, using curcumin-loaded nanoparticles seems to have a prospective clinical future. 
Table 1. An overview of polyphenol-loaded polymeric nanoparticles and their possible effects.

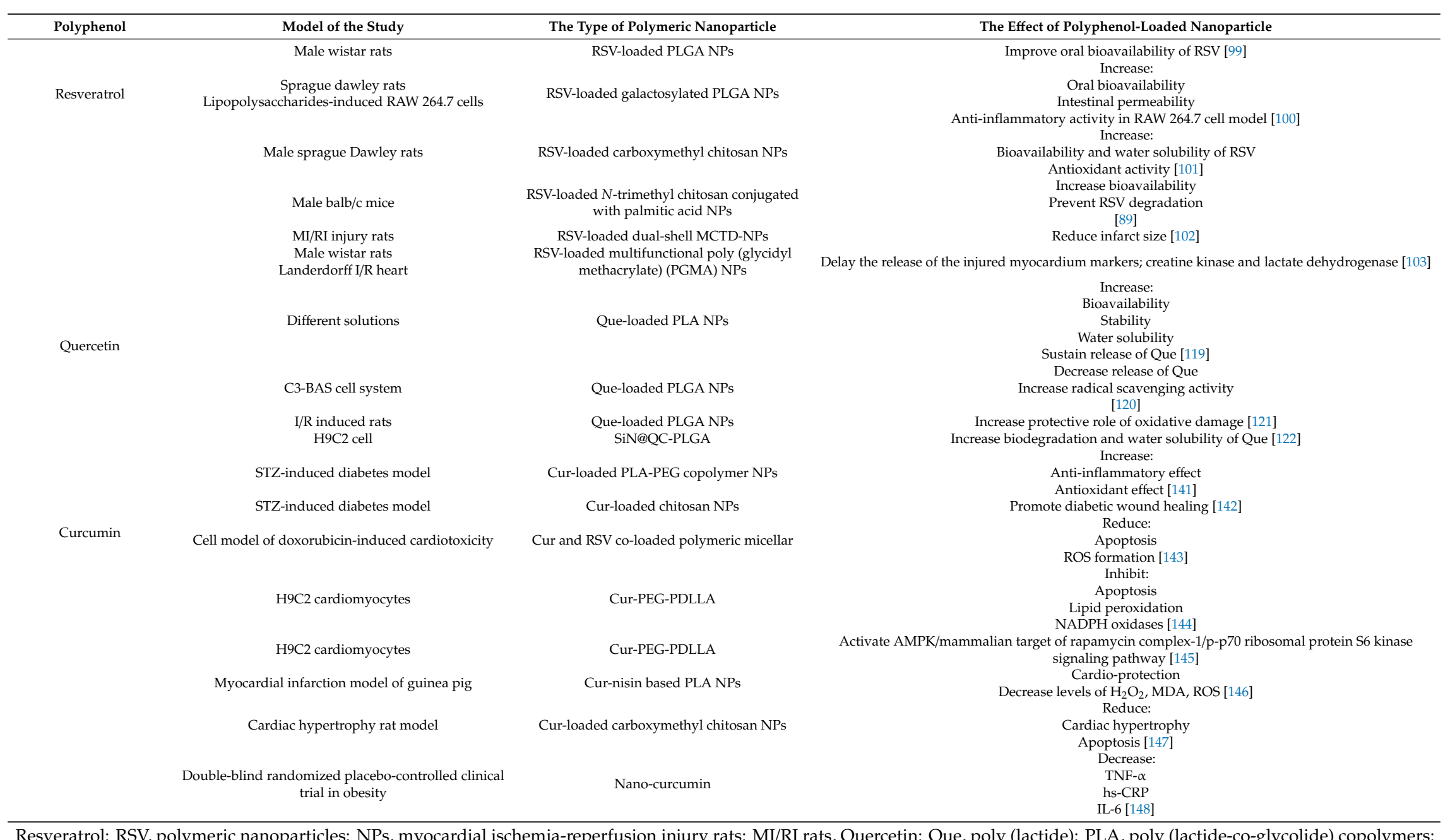

Resveratrol: RSV, polymeric nanoparticles: NPs, myocardial ischemia-reperfusion injury rats: MI/RI rats, Quercetin: Que, poly (lactide): PLA, poly (lactide-co-glycolide) copolymers: PLGA, Ischemia-Reperfusion: I/R, Super magnetic nano-silica@Que-loaded PLGA: SiN@QC-PLGA, Streptozotocin: STZ, Curcumin; Cur, Polylactide-poly (ethylene glycol): PLA-PEG, Reactive oxygen species: ROS, Curcumin-loaded copolymer PEG-Poly (ethylene glycol) methyl ether-block-poly ( $\mathrm{D}$, L lactide)-block-decane: Cur-PEG-PDLLA, hydrogen peroxide: $\mathrm{H}_{2} \mathrm{O}_{2}$, malondialdehyde: MDA, tumor necrosis factor $\alpha$ : TNF- $\alpha$, high sensitivity C-reactive protein: hs-CRP, interleukin-6: IL-6, human umbilical vein endothelial cells: HUVECs. 


\subsection{Effects of Cherry Extracts-Loaded Nanoparticles}

Cherries are a rich source of polyphenolic compounds, especially anthocyanins, phenolic acids, and flavonols. Cyanidin-3-glucoside and cyanidin-3-rutinoside are the major anthocyanins in both sour and sweet cherries. The major phenolic acids in cherries are neochlorogenic acid, chlorogenic acid, and $p$-coumaric acid derivatives. The amount of flavonol quercetin-3-rutinoside is also significant. The concentrations of anthocyanins and phenolic compounds can vary depending on the cultivar, stage of ripening, storage conditions, and harvest time. Cherry fruit also contains several organic acids, including malic, citric, ascorbic, and fumaric acids [149-151]. It is a good source of carotenoids, potassium, tryptophan, serotonin, and melatonin [150].

Cherry fruit has been widely studied for its nutritional properties and beneficial effects. Because of the high content of anthocyanins, phenolic acids, and flavonols, cherries have antioxidant, anti-inflammatory, and vasodilatory properties. In vitro studies have demonstrated that natural polyphenol-rich sweet cherry extracts are able to protect endothelial cells from oxidative stress [152]. Cherry extracts and their bioactive components can improve cardiovascular performance. The potential cardioprotective effects of cherry extracts or isolated anthocyanins have been demonstrated by their ability to increase NO production and antioxidant status, reduce lipid oxidation, and inhibit inflammation [153-155]. Furthermore, the cornelian cherry that contains a high amount of polyphenols has anti-atherosclerotic properties mainly based on its ability to curtail the inflammation process and improve endothelial dysfunction [59]. Dayar et al. [156] documented that different types of cornelian cherries have better beneficial effects than the powerful antioxidant coenzyme Q10 in obese Zucker rats. In contrast to coenzyme Q10, cornelian cherries decreased cholesterol, LDL levels, and ROS production, while increasing eNOS activity/expression [156]. In a randomized controlled trial, Chai et al. [157] showed that tart cherries can lower the systolic blood pressure and LDL cholesterol levels in older adults. Moreover, plasma levels of C-reactive protein, malondialdehyde, and oxLDL levels were significantly decreased after 12 weeks of tart cherry consumption [157].

However, the low bioavailability of polyphenols contained in cherry extracts is the major problem in terms of their use for therapeutic purposes. They have a poor intestinal absorption because of oxidation in the intestinal tract and rapid metabolic degradation in the liver. Thus, studies focused on targeted transport have been at the center of research [158]. The encapsulation of cherry extracts in nanoparticles based on chitosan derivatives improved the intestinal absorption of cherry polyphenols and enhanced their antioxidant and anti-inflammatory activity in an in vitro model based on human umbilical vein endothelial cells (HUVECs) [152]. HUVECs have also been used to investigate the effects of Crognola (Prunus avium L.) cherry-extract-loaded nanoparticles based on two different chitosan derivatives. Cherry extract loaded into S-protected thiolated derivative has been shown to have a much more efficient protective effect on $\mathrm{H}_{2} \mathrm{O}_{2}$-induced oxidative stress and a reduction in ROS production. Generally, the nanoparticles with protected thiol groups have demonstrated higher protective effects [159]. On the other hand, PLGA-based cherry extract encapsulation showed similar antioxidant activity as compared with the free extract. PLGA nanoparticles, however, demonstrated a low cytotoxicity and could allow for the administration of higher cherry extract doses [160]. To maintain the quality of sweet cherries and improve their antioxidant properties, Ma et al. [161] proposed a new delivery and protective system by immersing sweet cherries in nitric oxide-releasing chitosan nanoparticles (GSNO-CSNPs). GSNO-CS NPs were able to reduce ROS and glutathione and increase the antioxidant enzyme activities and the levels of ascorbic acid [161]. It seems that cherry-extract-loaded nanoparticles represent a promising tool not only in clinical studies, but in the food industry as well. Although the data concerning the cherry extracts loading on nanoparticles are interesting and promising, all other polyphenols have been used as pure compounds, so the evaluation/comparison of loading capacity and efficacy between the different types of particles requires further studies and is currently not possible. 


\section{Conclusions}

Different cardiovascular diseases, including hypertension, atherosclerosis, and heart failure, are accompanied by an increased production of ROS with subsequent decreased NO generation, leading to endothelial dysfunction. Many natural polyphenols are able to fight endothelial dysfunction through their ability to decrease ROS generation, induce the endogenous antioxidant enzymatic defense system, and increase activity/expression of eNOS. Different nanoparticles, including biodegradable polymeric nanoparticles, are able to increase the efficiency and reduce the degradability of natural polyphenols, thus increasing their beneficial abilities in the target tissues. Resveratrol, quercetin, curcumin, or cherry-extract-loaded polymeric nanoparticles have been shown to markedly reduce ROS formation, the inflammatory process, apoptosis, lipid peroxidation, cardiac hypertrophy, and even to delay myocardium injury due to ischemia/reperfusion. Nowadays, different copolymers and polymeric nanobio-composites are being developed with the aim of decreasing nanoparticle reactivity, toxicity, enhancing pharmacokinetics, and designing controlled release. They represent a promising tool for the delivery of natural polyphenols to target tissues and enhance their desirable effects, which is useful in the treatment of various diseases, including cardiovascular diseases.

Author Contributions: Conceptualization, O.P.; formal analysis, O.P., E.D., and M.C.; funding acquisition, O.P.; project administration, O.P. and M.C.; writing—original draft, O.P. and E.D.; writing-review and editing, O.P., E.D., and M.C. All authors have read and agreed to the published version of the manuscript.

Funding: This work was supported by national grant agencies APVV 14-0932 and VEGA 2/0112/19; 2/0132/20; 1/0035/19; 2/0151/18.

Conflicts of Interest: The authors declare no conflict of interest.

\section{References}

1. Ferenczyova, K.; Kalocayova, B.; Bartekova, M. Potential implications of quercetin and its derivatives in cardioprotection. Int. J. Mol. Sci. 2020, 21, 1585. [CrossRef] [PubMed]

2. Mitra, T.; Bhattacharya, R. Phytochemicals modulate cancer aggressiveness: A review depicting the anticancer efficacy of dietary polyphenols and their combinations. J. Cell. Physiol. 2020. [CrossRef] [PubMed]

3. Owona, B.A.; Abia, W.A.; Moundipa, P.F. Natural compounds flavonoids as modulators of inflammasomes in chronic diseases. Int. Immunopharmacol. 2020, 84, 106498. [CrossRef] [PubMed]

4. Wojcik, M.; Burzynska-Pedziwiatr, I.; Wozniak, L.A. A review of natural and synthetic antioxidants important for health and longevity. Curr. Med. Chem. 2010, 17, 3262-3288. [CrossRef]

5. Galleano, M.; Pechanova, O.; Fraga, C.G. Hypertension, nitric oxide, oxidants, and dietary plant polyphenols. Curr. Pharm. Biotechnol. 2010, 11, 837-848. [CrossRef]

6. Pechanova, O.; Bernatova, I.; Babál, P.; Martinez, M.C.; Kysela, S.; Stvrtina, S.; Andriantsitohaina, R. Red wine polyphenols prevent cardiovascular alterations in L-NAME-induced hypertension. J. Hypertens. 2004, 22, 1551-1559. [CrossRef]

7. Förstermann, U.; Xia, N.; Li, H. Roles of vascular oxidative stress and nitric oxide in the pathogenesis of atherosclerosis. Circ. Res. 2017, 120, 713-735. [CrossRef]

8. Ritchie, R.H.; Drummond, G.R.; Sobey, C.G.; De Silva, T.M.; Kemp-Harper, B.K. The opposing roles of NO and oxidative stress in cardiovascular disease. Pharmacol. Res. 2017, 116, 57-69. [CrossRef]

9. Pechanova, O.; Simko, F. Chronic antioxidant therapy fails to ameliorate hypertension: Potential mechanisms behind. J. Hypertens. Suppl. 2009, 27, S32-S36. [CrossRef]

10. Touyz, R.M.; Anagnostopoulou, A.; Camargo, L.L.; Rios, F.J.; Montezano, A.C. Vascular biology of superoxide-generating NADPH oxidase 5-implications in hypertension and cardiovascular disease. Antioxid. Redox Signal. 2019, 30, 1027-1040. [CrossRef]

11. Matsuno, K.; Yamada, H.; Iwata, K.; Jin, D.; Katsuyama, M.; Matsuki, M.; Takai, S.; Yamanishi, K.; Miyazaki, M.; Matsubara, H.; et al. Nox1 is involved in angiotensin II-mediated hypertension: A study in Nox1-deficient mice. Circulation 2005, 112, 2677-2685. [CrossRef]

12. Datla, S.R.; Griendling, K.K. Reactive oxygen species, NADPH oxidases, and hypertension. Hypertension 2010, 56, 325-330. [CrossRef] 
13. Rochette, L.; Lorin, J.; Zeller, M.; Guilland, J.C.; Lorgis, L.; Cottin, Y.; Vergely, C. Nitric oxide synthase inhibition and oxidative stress in cardiovascular diseases: Possible therapeutic targets? Pharmacol. Ther. 2013, 140, 239-257. [CrossRef]

14. Chen, D.D.; Chen, L.Y.; Xie, J.B.; Shu, C.; Yang, T.; Zhou, S.; Yuan, H.; Chen, A.F. Tetrahydrobiopterin regulation of eNOS redox function. Curr. Pharm. Des. 2014, 20, 3554-3562. [CrossRef]

15. Demougeot, C.; Prigent-Tessier, A.; Bagnost, T.; André, C.; Guillaume, Y.; Bouhaddi, M.; Marie, C.; Berthelot, A. Time course of vascular arginase expression and activity in spontaneously hypertensive rats. Life Sci. 2007, 80, 1128-1134. [CrossRef]

16. Galougahi, K.K.; Liu, C.C.; Gentile, C.; Kok, C.; Nunez, A.; Garcia, A.; Fry, N.A.; Davies, M.J.; Hawkins, C.L.; Rasmussen, H.H.; et al. Glutathionylation mediates angiotensin II-induced eNOS uncoupling, amplifying NADPH oxidase-dependent endothelial dysfunction. J. Am. Heart Assoc. 2014, 3, e000731. [CrossRef]

17. Barangi, S.; Hayes, A.W.; Karimi, G. The more effective treatment of atrial fibrillation applying the natural compounds; as NADPH oxidase and ion channel inhibitors. Crit. Rev. Food Sci. Nutr. 2018, 58, 1230-1241. [CrossRef]

18. Belin de Chantemele, E.J.; Stepp, D.W. Influence of obesity and metabolic dysfunction on the endothelial control in the coronary circulation. J. Mol. Cell. Cardiol. 2012, 52, 840-847. [CrossRef]

19. Savard, S.; Lavoie, P.; Villeneuve, C.; Agharazii, M.; Lebel, M.; Larivière, R. eNOS gene delivery prevents hypertension and reduces renal failure and injury in rats with reduced renal mass. Nephrol. Dial. Transplant. 2012, 27, 2182-2190. [CrossRef]

20. Zhou, M.S.; Schulman, I.H.; Raij, L. Nitric oxide, angiotensin II, and hypertension. Semin. Nephrol. 2004, 24, 366-378. [CrossRef]

21. Steinberg, D.; Witztum, J.L. Oxidized low-density lipoprotein and atherosclerosis. Arterioscler. Thromb. Vasc. Biol. 2010, 30, 2311-2316. [CrossRef] [PubMed]

22. Sedighi, M.; Bahmani, M.; Asgary, S.; Beyranvand, F.; Rafieian-Kopaei, M. A review of plant-based compounds and medicinal plants effective on atherosclerosis. J. Res. Med. Sci. 2017, 22, 30. [CrossRef] [PubMed]

23. Wang, G.; Zou, J.; Yu, X.; Yin, S.; Tang, C. The antiatherogenic function of kallistatin and its potential mechanism. Acta Biochim. Biophys. Sin. 2020, 52, 583-589. [CrossRef] [PubMed]

24. Binder, C.J.; Papac-Milicevic, N.; Witztum, J.L. Innate sensing of oxidation-specific epitopes in health and disease. Nat. Rev. Immunol. 2016, 16, 85-497. [CrossRef] [PubMed]

25. Xiao, X.; Yang, C.; Qu, S.L.; Shao, Y.D.; Zhou, C.Y.; Chao, R.; Huang, L.; Zhang, C. S100 proteins in atherosclerosis. Clin. Chim. Acta 2020, 502, 293-304. [CrossRef] [PubMed]

26. Marcos-Ramiro, B.; García-Weber, D.; Millán, J. TNF-induced endothelial barrier disruption: Beyond actin and Rho. Thromb. Haemost. 2014, 112, 1088-1102. [CrossRef] [PubMed]

27. Kuang, Y.; Liu, H.; Guo, S.; Wang, Y.; Zhang, H.; Qiao, Y. The antagonist of P2Y11 receptor NF157 ameliorates oxidized LDL-induced vascular endothelial inflammation. Artif. Cells Nanomed. Biotechnol. 2019, 47, 1839-1845. [CrossRef]

28. Boyle, J.J. Macrophage activation in atherosclerosis: Pathogenesis and pharmacology of plaque rupture. Curr. Vasc. Pharmacol. 2005, 3, 63-68. [CrossRef]

29. Basta, G.; Schmidt, A.M.; De Caterina, R. Advanced glycation end products and vascular inflammation: Implications for accelerated atherosclerosis in diabetes. Cardiovasc. Res. 2004, 63, 582-592. [CrossRef]

30. Maksimenko, A.V.; Vavaev, A.V. Antioxidant enzymes as potential targets in cardioprotection and treatment of cardiovascular diseases. Enzyme antioxidants: The next stage of pharmacological counterwork to the oxidative stress. Heart Int. 2012, 7, e3. [CrossRef]

31. Ul Ain, Q.; Chung, H.; Chung, J.Y.; Choi, J.H.; Kim, Y.H. Amelioration of atherosclerotic inflammation and plaques via endothelial adrenoceptor-targeted eNOS gene delivery using redox-sensitive polymer bearing 1-arginine. J. Control. Release 2017, 262, 72-86. [CrossRef] [PubMed]

32. Fraccarollo, D.; Berger, S.; Galuppo, P.; Kneitz, S.; Hein, L.; Schütz, G.; Frantz, S.; Ertl, G.; Bauersachs, J. Deletion of cardiomyocyte mineralocorticoid receptor ameliorates adverse remodeling after myocardial infarction. Circulation 2011, 123, 400-408. [CrossRef] [PubMed]

33. Johar, S.; Cave, A.C.; Narayanapanicker, A.; Grieve, D.J.; Shah, A.M. Aldosterone mediates angiotensin II-induced interstitial cardiac fibrosis via a Nox2-containing NADPH oxidase. FASEB J. 2006, 20, 1546-1548. [CrossRef] [PubMed] 
34. Hiroyuki Tsutsui, H.; Kinugawa, S.; Matsushima, S. Oxidative stress and heart failure. Am. J. Physiol. Heart Circ. Physiol. 2011, 301, H2181-H2190. [CrossRef]

35. Ahn, B.; Coblentz, P.D.; Beharry, A.W.; Patel, N.; Judge, A.R.; Moylan, J.S.; Hoopes, C.H.W.; Bonnell, M.R.; Ferreira, L.F. Diaphragm abnormalities in patients with end-stage heart failure: NADPH oxidase upregulation and protein oxidation. Front. Physiol. 2017, 7, 686. [CrossRef]

36. Doerries, C.; Grote, K.; Hilfiker-Kleiner, D.; Luchtefeld, M.; Schaefer, A.; Holland, S.M.; Sorrentino, S.; Manes, C.; Schieffer, B.; Drexler, H.; et al. Critical role of the NAD(P)H oxidase subunit p47phox for left ventricular remodeling/dysfunction and survival after myocardial infarction. Circ. Res. 2007, 100, 894-903. [CrossRef]

37. Zhang, Y.H.; Casadei, B. Sub-cellular targeting of constitutive NOS in health and disease. J. Mol. Cell. Cardiol. 2012, 52, 341-350. [CrossRef]

38. Janssens, S.; Pokreisz, P.; Schoonjans, L.; Pellens, M.; Vermeersch, P.; Tjwa, M.; Jans, P.; Scherrer-Crosbie, M.; Picard, M.H.; Szelid, Z.; et al. Cardiomyocyte-specific overexpression of nitric oxide synthase 3 improves left ventricular performance and reduces compensatory hypertrophy after myocardial infarction. Circ. Res. 2004, 94, 1256-1262. [CrossRef]

39. Munzel, T.; Daiber, A.; Gori, T. Nitrate therapy: New aspects concerning molecular action and tolerance. Circulation 2011, 123, 2132-2144. [CrossRef]

40. Ruiz-Hurtado, G.; Delgado, C. Nitric oxide pathway in hypertrophied heart: New therapeutic uses of nitric oxide donors. J. Hypertens. 2010, 28, S56-S61. [CrossRef]

41. Brglez Mojzer, E.; Knez Hrnčič, M.; Škerget, M.; Knez, Ž.; Bren, U. Polyphenols: Extraction Methods, Antioxidative Action, Bioavailability and Anticarcinogenic Effects. Molecules 2016, 21, 901. [CrossRef]

42. Ohara, M.; Ohyama, Y. Delivery and application of dietary polyphenols to target organs, tissues and intracellular organelles. Curr. Drug Metab. 2014, 15, 37-47. [CrossRef] [PubMed]

43. Sadowska-Bartosz, I.; Bartosz, G. Effect of antioxidants supplementation on aging and longevity. BioMed Res. Int. 2014, 2014, 404680. [CrossRef] [PubMed]

44. Suzuki, A.; Yamamoto, N.; Jokura, H.; Yamamoto, M.; Fujii, A.; Tokimitsu, I.; Saito, I. Chlorogenic acid attenuates hypertension and improves endothelial function in spontaneously hypertensive rats. J. Hypertens. 2006, 24, 1065-1073. [CrossRef] [PubMed]

45. Akila, P.; Vennila, L. Chlorogenic acid a dietary polyphenol attenuates isoproterenol induced myocardial oxidative stress in rat myocardium: An in vivo study. Biomed. Pharmacother. 2016, 84, 208-214. [CrossRef] [PubMed]

46. Wei, H.; Li, H.; Wan, S.P.; Zeng, Q.T.; Cheng, L.X.; Jiang, L.L.; Peng, Y.D. Cardioprotective effects of malvidin against isoproterenol-induced myocardial infarction in rats: A mechanistic study. Med. Sci. Monit. 2017, 23, 2007-2016. [CrossRef] [PubMed]

47. Suchal, K.; Malik, S.; Gamad, N.; Malhotra, R.K.; Goyal, S.N.; Chaudhary, U.; Bhatia, J.; Ojha, S.; Arya, D.S. Kaempferol attenuates myocardial ischemic injury via inhibition of MAPK signaling pathway in experimental model of myocardial ischemia-reperfusion injury. Oxid. Med. Cell. Longev. 2016, 2016, 7580731. [CrossRef] [PubMed]

48. Wang, Y.; Zhang, Z.Z.; Wu, Y.; Ke, J.J.; He, X.H.; Wang, Y.L. Quercetin postconditioning attenuates myocardial ischemia/reperfusion injury in rats through the PI3K/Akt pathway. Braz. J. Med. Biol. Res. 2013, 46, 861-867. [CrossRef] [PubMed]

49. Almajdoob, S.; Hossain, E.; Anand-Srivastava, M.B. Resveratrol attenuates hyperproliferation of vascular smooth muscle cells from spontaneously hypertensive rats: Role of ROS and ROS-mediated cell signaling. Vasc. Pharmacol. 2018, 101, 48-56. [CrossRef]

50. Howitz, K.T.; Bitterman, K.J.; Cohen, H.Y.; Lamming, D.W.; Lavu, S.; Wood, J.G.; Zipkin, R.E.; Chung, P.; Kisielewski, A.; Zhang, L.L.; et al. Small molecule activators of sirtuins extend Saccharomyces cerevisiae lifespan. Nature 2003, 425, 191-196. [CrossRef]

51. Park, S.-J.; Ahmad, F.; Philp, A.; Baar, K.; Williams, T.; Luo, H.; Ke, H.; Rehmann, H.; Taussig, R.; Brown, A.L.; et al. Resveratrol ameliorates aging-related metabolic phenotypes by inhibiting cAMP phosphodiesterases. Cell 2012, 148, 421-433. [CrossRef] [PubMed]

52. Xia, N.; Strand, S.; Schlufter, F.; Siuda, D.; Reifenberg, G.; Kleinert, H.; Forstermann, U.; Li, H. Role of SIRT1 and FOXO factors in eNOS transcriptional activation by resveratrol. Nitric Oxide 2013, 32, 29-35. [CrossRef] [PubMed] 
53. Ungvari, Z.; Bagi, Z.; Feher, A.; Recchia, F.A.; Sonntag, W.E.; Pearson, K.; de Cabo, R.; Csiszar, A. Resveratrol confers endothelial protection via activation of the antioxidant transcription factor Nrf2. Am. J. Physiol. Heart Circ. Physiology 2010, 299, H18-H24. [CrossRef] [PubMed]

54. Mattera, R.; Benvenuto, M.; Giganti, M.G.; Tresoldi, I.; Pluchinotta, F.R.; Bergante, S.; Tettamanti, G.; Masuelli, L.; Manzari, V.; Modesti, A.; et al. Effects of polyphenols on oxidative stress-mediated injury in cardiomyocytes. Nutrients 2017, 9, 523. [CrossRef] [PubMed]

55. Klinge, C.M.; Wickramasinghe, N.S.; Ivanova, M.M.; Dougherty, S.M. Resveratrol stimulates nitric oxide production by increasing estrogen receptor alpha-Src-caveolin-1 interaction and phosphorylation in human umbilical vein endothelial cells. FASEB J. 2008, 22, 2185-2197. [CrossRef] [PubMed]

56. Wyckoff, M.H.; Chambliss, K.L.; Mineo, C.; Yuhanna, I.S.; Mendelsohn, M.E.; Mumby, S.M.; Shaul, P.W. Plasma membrane estrogen receptors are coupled to endothelial nitric-oxide synthase through Galpha(i). J. Biol. Chem. 2001, 276, 27071-27076. [CrossRef]

57. Lan, C.; Chen, X.; Zhang, Y.; Wang, W.; Wang, W.E.; Liu, Y.; Cai, Y.; Ren, H.; Zheng, S.; Zhou, L.; et al. Curcumin prevents strokes in stroke-prone spontaneously hypertensive rats by improving vascular endothelial function. BMC Cardiovasc. Disord. 2018, 18, 43. [CrossRef]

58. Kim, Y.S.; Ahn, Y.; Hong, M.H.; Joo, S.Y.; Kim, K.H.; Sohn, I.S.; Park, H.W.; Hong, Y.J.; Kim, J.H.; Kim, W.; et al. Curcumin attenuates inflammatory responses of TNF- $\alpha$-stimulated human endothelial cells. J. Cardiovasc. Pharmacol. 2007, 50, 41-49. [CrossRef]

59. Lietava, J.; Beerova, N.; Klymenko, S.V.; Panghyova, E.; Varga, I.; Pechanova, O. Effects of cornelian cherry on atherosclerosis and its risk factors. Oxid. Med. Cell. Longev. 2019, 2019, 2515270. [CrossRef]

60. Kim, J.Y.; Shim, S.H. Anti-atherosclerotic effects of fruits of Vitex rotundifolia and their isolated compounds via inhibition of human LDL and HDL oxidation. Biomolecules 2019, 9, 727. [CrossRef]

61. Furlan, V.; Konc, J.; Bren, U. Inverse Molecular Docking as a Novel Approach to Study Anticarcinogenic and Anti-Neuroinflammatory Effects of Curcumin. Molecules 2018, 23, 3351. [CrossRef] [PubMed]

62. Kores, K.; Lešnik, S.; Bren, U.; Janežič, D.; Konc, J. Discovery of Novel Potential Human Targets of Resveratrol by Inverse Molecular Docking. J. Chem. Inf. Model. 2019, 59, 2467-2478. [CrossRef] [PubMed]

63. Shastri, V.P. Non-degradable biocompatible polymers in medicine: Past, present and future. Curr. Pharm. Biotechnol. 2003, 4, 331-337. [CrossRef] [PubMed]

64. Elsabahy, M.; Wooley, K.L. Design of polymeric nanoparticles for biomedical delivery applications. Chem. Soc. Rev. 2012, 41, 2545-2561. [CrossRef]

65. Banik, B.L.; Fattahi, P.; Brown, J.L. Wiley Polymeric nanoparticles: The future of nanomedicine. Interdiscip. Rev. Nanomed. Nanobiotechnol. 2016, 8, 271-299. [CrossRef]

66. Morales, J.O.; Sepulveda-Rivas, S.; Oyarzun-Ampuero, F.; Lavandero, S.; Kogan, M.J. Novel nanostructured polymeric carriers to enable drug delivery for cardiovascular diseases. Curr. Pharm. Des. 2015, 21, 4276-4284. [CrossRef]

67. Danhier, F.; Ansorena, E.; Silva, J.M.; Coco, R.; Le Breton, A.; Préat, V. PLGA-based nanoparticles: An overview of biomedical applications. J. Control. Release 2012, 161, 505-522. [CrossRef]

68. Narancic, T.; Cerrone, F.; Beagan, N.; O'Connor, K.E. Recent Advances in Bioplastics: Application and Biodegradation. Polymers 2020, 12, 920. [CrossRef]

69. Ding, B.S.; Dziubla, T.; Shuvaev, V.V.; Muro, S.; Muzykantov, V.R. Advanced drug delivery systems that target the vascular endothelium. Mol. Interv. 2006, 6, 98-112. [CrossRef]

70. Discher, B.M.; Won, Y.Y.; Ege, D.S.; Lee, J.C.; Bates, F.S.; Discher, D.E.; Hammer, D.A. Polymersomes: Tough vesicles made from diblock copolymers. Sciences 1999, 284, 1143-1146. [CrossRef]

71. Photos, P.J.; Bacakova, L.; Discher, B.; Bates, F.S.; Discher, D.E. Polymer vesicles in vivo: Correlations with PEG molecular weight. J. Control. Release 2003, 90, 323-334. [CrossRef]

72. Kona, S.; Dong, J.-F.; Liu, Y.; Tan, J.; Nguyen, K.T. Biodegradable nanoparticles mimicking platelet binding as a targeted and controlled drug delivery system. Int. J. Pharm. 2012, 423, 516-524. [CrossRef] [PubMed]

73. Singh, B.; Garg, T.; Goyal, A.K.; Rath, G. Recent advancements in the cardiovascular drug carriers. Artif. Cells Nanomed. Biotechnol. 2016, 44, 216-225. [CrossRef] [PubMed]

74. Farah, S.; Anderson, D.G.; Langer, R. Physical and mechanical properties of PLA, and their functions in widespread applications-A comprehensive review. Adv. Drug Deliv. Rev. 2016, 107, 367-392. [CrossRef] 
75. Chenthamara, D.; Subramaniam, S.; Ramakrishnan, S.G.; Krishnaswamy, S.; Essa, M.M.; Lin, F.H.; Qoronfleh, M.W. Therapeutic efficacy of nanoparticles and routes of administration. Biomater. Res. 2019, 23, 20. [CrossRef]

76. Takahama, H.; Shigematsu, H.; Asai, T.; Matsuzaki, T.; Sanada, S.; Fu, H.Y.; Okuda, K.; Yamato, M.; Asanuma, H.; Asano, Y.; et al. Liposomal amiodarone augments anti-arrhythmic effects and reduces hemodynamic adverse effects in an ischemia/reperfusion rat model. Cardiovasc. Drugs Ther. 2013, 27, 125-132. [CrossRef]

77. Pechanova, O.; Barta, A.; Koneracka, M.; Zavisova, V.; Kubovcikova, M.; Klimentova, J.; Torok, J.; Zemancikova, A.; Cebova, M. protective effects of nanoparticle-loaded aliskiren on cardiovascular system in spontaneously hypertensive rats. Molecules 2019, 24, 2710. [CrossRef]

78. Dudhipala, N.; Janga, K.Y.; Gorre, T. Comparative study of nisoldipine-loaded nanostructured lipid carriers and solid lipid nanoparticles for oral delivery: Preparation, characterization, permeation and pharmacokinetic evaluation. Artif. Cells Nanomed. Biotechnol. 2018, 46, 616-625. [CrossRef]

79. Kim, Y.I.; Fluckiger, L.; Hoffman, M.; Lartaud-Idjouadiene, I.; Atkinson, J.; Maincent, P. The antihypertensive effect of orally administered nifedipine-loaded nanoparticles in spontaneously hypertensive rats. Br. J. Pharmacol. 1997, 120, 399-404. [CrossRef]

80. Shah, U.; Joshi, G.; Sawant, K. Improvement in antihypertensive and antianginal effects of felodipine by enhanced absorption from PLGA nanoparticles optimized by factorial design. Mater. Sci. Eng. C. Mater. Biol. Appl. 2014, 35, 153-163. [CrossRef]

81. Seabra, A.B.; Justo, G.Z.; Haddad, P.S. State of the art, challenges and perspectives in the design of nitric oxide-releasing polymeric nanomaterials for biomedical applications. Biotechnol. Adv. 2015, 33, 1370-1379. [CrossRef]

82. Osako, M.K.; Nakagami, H.; Morishita, R. Modification of decoy oligodeoxynucleotides to achieve the stability and therapeutic efficacy. Curr. Top. Med. Chem. 2012, 12, 1603-1607. [CrossRef] [PubMed]

83. Kimura, S.; Egashira, K.; Chen, L.; Nakano, K.; Iwata, E.; Miyagawa, M.; Tsujimoto, H.; Hara, K.; Morishita, R.; Sueishi, K.; et al. Nanoparticle-mediated delivery of nuclear factor kappaB decoy into lungs ameliorates monocrotaline-induced pulmonary arterial hypertension. Hypertension 2009, 53, 877-883. [CrossRef] [PubMed]

84. Nel, A.; Xia, T.; Mädler, L.; Li, N. Toxic potential of materials at the nanolevel. Sciences 2006, 311, $622-627$. [CrossRef] [PubMed]

85. Bonnefont-Rousselot, D. Resveratrol and cardiovascular diseases. Nutrients 2016, 8, 250. [CrossRef]

86. Neves, A.R.; Lucio, M.; Lima, J.L.; Reis, S. Resveratrol in medicinal chemistry: A critical review of its pharmacokinetics, drug-delivery, and membrane interactions. Curr. Med. Chem. 2012, 19, 1663-1681. [CrossRef]

87. Santos, A.C.; Veiga, F.J.; Sequeira, J.A.D.; Fortuna, A.; Falcão, A.; Pereira, I.; Pattekari, P.; Fontes-Ribeiro, C.; Ribeiro, A.J. First-time oral administration of resveratrol-loaded layer-by-layer nanoparticles to rats-A pharmacokinetics study. Analyst 2019, 144, 2062-2079. [CrossRef]

88. Breuss, J.M.; Atanasov, A.G.; Uhrin, P. Resveratrol and its effects on the vascular system. Int. J. Mol. Sci. 2019, 20, 1523. [CrossRef]

89. Intagliata, S.; Modica, M.N.; Santagati, L.M.; Montenegro, L. Strategies to improve resveratrol systemic and topical bioavailability: An update. Antioxidant 2019, 8, 244. [CrossRef]

90. de la Lastra, C.A.; Villegas, I. Resveratrol as an antioxidant and pro-oxidant agent: Mechanisms and clinical implications. Biochem. Soc. Trans. 2007, 35, 1156-1160. [CrossRef]

91. Liao, P.C.; Ng, L.T.; Lin, L.T.; Richardson, C.D.; Wang, G.-H.; Lin, C.-C. Resveratrol arrests cell cycle and induces apoptosis in human hepatocellular carcinoma Huh-7 cells. J. Med. Food. 2010, 13, 1415-1423. [CrossRef] [PubMed]

92. Baur, J.A.; Sinclair, D.A. Therapeutic potential of resveratrol: The in vivo evidence. Nat. Rev. Drug Discov. 2006, 5, 493-506. [CrossRef] [PubMed]

93. Wallerath, T.; Deckert, G.; Ternes, T.; Anderson, H.; Li, H.; Witte, K.; Förstermann, U. Resveratrol, a polyphenolic phytoalexin present in red wine, enhances expression and activity of endothelial nitric oxide synthase. Circulation 2002, 106, 1652-1658. [CrossRef] [PubMed]

94. Pervaiz, S. Resveratrol: From grapevines to mammalian biology. FASEB J. 2003, 17, 1975-1985. [CrossRef] 
95. Marier, J.F.; Vachon, P.; Gritsas, A.; Zhang, J.; Moreau, J.-P.; Ducharme, M.P. Metabolism and disposition of resveratrol in rats: Extent of absorption, glucuronidation, and enterohepatic recirculation evidenced by a linked-rat model. J. Pharmacol. Exp. Ther. 2002, 302, 369-373. [CrossRef]

96. Zhang, H.; Zhang, J.; Ungvari, Z. Resveratrol improves endothelial function: Role of TNF \{alpha\} and vascular oxidative stress. Arterioscler. Thromb. Vasc. Biol. 2009, 29, 1164-1171. [CrossRef]

97. Fremont, L. Minireview-Biological effects of resveratrol. Life Sci. 2000, 66, 663-673. [CrossRef]

98. Walle, T. Bioavailability of resveratrol. Ann. N. Y. Acad. Sci. 2011, 1215, 9-15. [CrossRef]

99. Singh, G.; Pai, R.S. Optimized PLGA nanoparticle platform for orally dosed trans-resveratrol with enhanced bioavailability potential. Expert Opin. Drug Deliv. 2014, 11, 647-659. [CrossRef]

100. Siu, F.Y.; Ye, S.; Lin, H.; Li, S. Galactosylated PLGA nanoparticles for the oral delivery of resveratrol: Enhanced bioavailability and in vitro anti-inflammatory activity. Int. J. Nanomed. 2018, 13, 4133-4144. [CrossRef]

101. Zu, Y.; Zhang, Y.; Wang, W.; Zhao, X.; Han, X.; Wang, K.; Ge, Y. Preparation and in vitro/in vivo evaluation of resveratrol-loaded carboxymethyl chitosan nanoparticles. Drug Deliv. 2016, 23, 981-991. [CrossRef] [PubMed]

102. Cheng, Y.; Liu, D.Z.; Zhang, C.X.; Cui, H.; Liu, M.; Zhang, B.; Mei, Q.B.; Lu, Z.F.; Zhou, S.Y. Mitochondria-targeted antioxidant delivery for precise treatment of myocardial ischemia-reperfusion injury through a multistage continuous targeted strategy. Nanomedicine 2019, 16, 236-249. [CrossRef] [PubMed]

103. Hardy, N.; Viola, H.M.; Johnstone, V.P.; Clemons, T.D.; Szappanos, H.C.; Singh, R.; Smith, N.M.; Iyer, K.S.; Hool, L.C. Nanoparticle-mediated dual delivery of an antioxidant and a peptide against the L-Type Ca2+ channel enables simultaneous reduction of cardiac ischemia-reperfusion injury. ACS Nano 2015, 9, 279-289. [CrossRef] [PubMed]

104. Kasikci, M.B.; Bagdatlioglu, N. Bioavailability of quercetin. Curr. Res. Nutr. Food Sci. 2016, 4, $146-151$. [CrossRef]

105. David, A.V.A.; Arulmoli, R.; Parasuraman, S. Overviews of biological importance of quercetin: A bioactive flavonoid. Pharmacogn. Rev. 2016, 10, 84-89. [CrossRef]

106. Miles, S.L.; McFarland, M.; Niles, R.M. Molecular and physiological actions of quercetin: Need for clinical trials to assess its benefits in human diseases. Nutr. Rev. 2014, 72, 720-734. [CrossRef]

107. Salehi, B.; Machin, L.; Monzote, L.; Sharifi-Rad, J.; Ezzat, S.M.; Salem, M.A.; Merghany, R.M.; El Mahdy, N.M.; Kılıç, C.S.; Sytar, O.; et al. Therapeutic potential of quercetin: New insights and perspectives for human health. ACS Omega 2020, 5, 11849-11872. [CrossRef]

108. Wu, T.H.; Yen, F.L.; Lin, L.T.; Tsai, T.R.; Lin, C.C.; Cham, T.M. Preparation, physicochemical characterization, and antioxidant effects of quercetin nanoparticles. Int. J. Pharm. 2008, 346, 160-168. [CrossRef]

109. Patel, R.V.; Mistry, B.M.; Shinde, S.K.; Syed, R.; Singh, V.; Shin, H.S. Therapeutic potential of quercetin as a cardiovascular agent. Eur. J. Med. Chem. 2018, 155, 889-904. [CrossRef]

110. Xiao, X.; Shi, D.; Liu, L.; Wang, J.; Xie, X.; Kang, T.; Deng, W. Quercetin suppresses cyclooxygenase-2 expression and angiogenesis through inactivation of P300 signaling. PLoS ONE 2011, 6, e22934. [CrossRef]

111. García-Mediavilla, V.; Crespo, I.; Collado, P.S.; Esteller, A.; Sánchez-Campos, S.; Tuñón, M.J.; GonzálezGallego, J. The anti-inflammatory flavones quercetin and kaempferol cause inhibition of inducible nitric oxide synthase, cyclooxygenase-2 and reactive C-protein, and down-regulation of the nuclear factor kappaB pathway in Chang Liver cells. Eur. J. Pharmacol. 2007, 557, 221-229. [CrossRef] [PubMed]

112. Yang, D.K.; Kang, H.S. Anti-diabetic effect of cotreatment with quercetin and resveratrol in streptozotocin-induced diabetic rats. Biomol. Ther. 2018, 26, 130-138. [CrossRef] [PubMed]

113. Mahesh, T.; Menon, V.P. Quercetin allievates oxidative stress in streptozotocin-induced diabetic rats. Phytother. Res. 2004, 18, 123-127. [CrossRef] [PubMed]

114. Porcu, E.P.; Cossu, M.; Rassu, G.; Giunchedi, P.; Cerri, G.; Pourova, J.; Najmanova, I.; Migkos, T.; Pilarova, V.; Novakova, L.; et al. Aqueous injection of quercetin: An approach for confirmation of its direct in vivo cardiovascular effects. Int. J. Pharm. 2018, 541, 224-233. [CrossRef]

115. Kleemann, R.; Verschuren, L.; Morrison, M.; Zadelaar, S.; van Erk, M.J.; Wielinga, P.Y.; Kooistra, T. Anti-inflammatory, anti-proliferative and anti-atherosclerotic effects of quercetin in human in vitro and in vivo models. Atherosclerosis 2011, 218, 44-52. [CrossRef] 
116. Zahedi, M.; Ghiasvand, R.; Feizi, A.; Asgari, G.; Darvish, L. Does quercetin improve cardiovascular risk factors and inflammatory biomarkers in women with type 2 diabetes: A double-blind randomized controlled clinical trial. Int. J. Prev. Med. 2013, 4, 777-785.

117. Ganz, P.; Vita, J.A. Testing endothelial vasomotor function: Nitric oxide, a multipotent molecule. Circulation 2003, 108, 2049-2053. [CrossRef]

118. Giannouli, M.; Karagkiozaki, V.; Pappa, F.; Moutsios, I.; Gravalidis, C.; Logothetidis, L. Fabrication of quercetin-loaded PLGA nanoparticles via electrohydrodynamic atomization for cardiovascular disease. Mater. Today Proc. 2018, 5, 15998-16005. [CrossRef]

119. Kumari, A.; Yadav, S.K.; Pakade, Y.B.; Singh, B.; Yadav, S.C. Development of biodegradable nanoparticles for delivery of quercetin. Colloids Surf. B Biointerfaces 2010, 80, 184-192. [CrossRef]

120. Pool, H.; Quintanar, D.; de Dios Figueroa, K.; Marinho Mano, C.; Bechara, J.E.H.; Godínez, L.A.; Mendoza, S. Antioxidant effects of quercetin and catechin encapsulated into PLGA nanoparticles. J. Nanomater. 2012, 2012, 12. [CrossRef]

121. Ghosh, A.; Sarkar, S.; Mandal, A.K.; Das, N. Neuroprotective role of nanoencapsulated quercetin in combating ischemia-reperfusion induced neuronal damage in young and aged rats. PLoS ONE 2013, 8, e57735. [CrossRef] [PubMed]

122. Wang, L.; Feng, M.; Li, Y.; Du, Y.; Wang, H.; Chen, Y.; Li, L. Fabrication of superparamagnetic nano-silica@ quercetin-encapsulated PLGA nanocomposite: Potential application for cardiovascular diseases. J. Photochem. Photobiol. B 2019, 196, 111508. [CrossRef] [PubMed]

123. Ghosh, S.; Banerjee, S.; Sil, P.C. The beneficial role of curcumin on inflammation, diabetes and neurodegenerative disease: A recent update. Food Chem. Toxicol. 2015, 83, 111-124. [CrossRef] [PubMed]

124. Prasad, S.; Gupta, S.C.; Tyagi, A.K.; Aggarwal, B.B. Curcumin, a component of golden spice: From bedside to bench and back. Biotechnol. Adv. 2014, 32, 1053-1064. [CrossRef]

125. Kunnumakkara, A.B.; Bordoloi, D.; Padmavathi, G.; Monisha, J.; Roy, N.K.; Prasad, S.; Aggarwal, B.B. Curcumin, the golden nutraceutical: Multitargeting for multiple chronic diseases. Br. J. Pharmacol. 2017, 174, 1325-1348. [CrossRef]

126. Salehi, B.; Del Prado-Audelo, M.L.; Cortés, H.; Leyva Gomez, G.; Stojanovic Radic, Z.; Singh, Y.D.; Patra, J.K.; Das, G.; Martins, N.; Martorell, M.; et al. therapeutic applications of curcumin nanomedicine formulations in cardiovascular diseases. J. Clin. Med. 2020, 9, 746. [CrossRef]

127. Priyadarsini, K.I. The chemistry of curcumin: From extraction to therapeutic agent. Molecules 2014, 19, 20091-20112. [CrossRef]

128. Li, H.; Sureda, A.; Devkota, H.P.; Pittala, V.; Barreca, D.; Silva, A.S.; Tewari, D.; Xu, S.; Nabavi, S.M. Curcumin, the golden spice in treating cardiovascular diseases. Biotechnol. Adv. 2020, 38, 107343. [CrossRef]

129. Zhao, J.F.; Ching, L.C.; Huang, Y.C.; Chen, C.Y.; Chiang, A.N.; Kou, Y.R.; Shyue, S.K.; Lee, T.S. Molecular mechanism of curcumin on the suppression of cholesterol accumulation in macrophage foam cells and atherosclerosis. Mol. Nutr. Food Res. 2012, 56, 691-701. [CrossRef]

130. Shishodia, S.; Singh, T.; Chaturvedi, M.M. Modulation of transcription factors by curcumin. Adv. Exp. Med. Biol. 2007, 595, 127-148. [CrossRef]

131. Ganjali, S.; Blesso, C.N.; Banach, M.; Pirro, M.; Majeed, M.; Sahebkar, A. Effects of curcumin on HDL functionality. Pharmacol. Res. 2017, 119, 208-218. [CrossRef] [PubMed]

132. Sahebkar, A. Curcuminoids for the management of hypertriglyceridaemia. Nat. Rev. Cardiol. 2014, 11, 123. [CrossRef] [PubMed]

133. Motterlini, R.; Foresti, R.; Bassi, R.; Green, C.J. Curcumin, an antioxidant and anti-inflammatory agent, induces heme oxygenase- 1 and protects endothelial cells against oxidative stress. Free Radic. Biol. Med. 2000, 28, 1303-1312. [CrossRef]

134. Pae, H.O.; Jeong, G.S.; Jeong, S.O.; Kim, H.S.; Kim, S.A.; Kim, Y.C.; Yoo, S.J.; Kim, H.D.; Chung, H.T. Roles of heme oxygenase-1 in curcumin-induced growth inhibition in rat smooth muscle cells. Exp. Mol. Med. 2007, 39, 267-277. [CrossRef] [PubMed]

135. Ramirez Bosca, A.; Soler, A.; Carrion-Gutierrez, M.A.; Pamies Mira, D.; Pardo Zapata, J.; Diaz-Alperi, J.; Bernd, A.; Quintanilla Almagro, E.; Miquel, J. An hydroalcoholic extract of Curcuma longa lowers the abnormally high values of human-plasma fibrinogen. Mech. Ageing Dev. 2000, 114, 207-210. [CrossRef] 
136. Shin, S.K.; Ha, T.Y.; McGregor, R.A.; Choi, M.S. Long-term curcumin administration protects against atherosclerosis via hepatic regulation of lipoprotein cholesterol metabolism. Mol. Nutr. Food Res. 2011, 55, 1829-1840. [CrossRef] [PubMed]

137. Wahlstrom, B.; Blennow, G. A study on the fate of curcumin in the rat. Acta Pharmacol. Toxicol. (Copenh.) 1978, 43, 86-92. [CrossRef]

138. Kumar, A.; Ahuja, A.; Ali, J.; Baboota, S. Conundrum and therapeutic potential of curcumin in drug delivery. Crit. Rev. Ther. Drug Carr. Syst. 2010, 27, 279-312. [CrossRef]

139. Shimizu, K.; Funamoto, M.; Sunagawa, Y.; Shimizu, S.; Katanasaka, Y.; Miyazaki, Y.; Wada, H.; Hasegawa, K.; Morimoto, T. Anti-inflammatory action of curcumin and its use in the treatment of lifestyle-related diseases. Eur. Cardiol. 2019, 14, 117-122. [CrossRef]

140. Aggarwal, B.B.; Harikumar, K.B. Potential therapeutic effects of curcumin, the anti-inflammatory agent, against neurodegenerative, cardiovascular, pulmonary, metabolic, autoimmune and neoplastic diseases. Int. J. Biochem. Cell Biol. 2009, 41, 40-59. [CrossRef]

141. El-Naggar, M.E.; Al-Joufi, F.; Anwar, M.; Attia, M.A.; El-Bana, M.A. Curcumin-loaded PLA-PEG copolymer nanoparticles for treatment of liver inflammation in streptozotocin-induced diabetic rats. Colloids Surf. B Biointerfaces 2019, 177, 389-398. [CrossRef]

142. Karri, V.V.; Kuppusamy, G.; Talluri, S.V.; Mannemala, S.S.; Kollipara, R.; Wadhwani, A.D.; Mulukutla, S.; Raju, K.R.S.; Malayandi, R. Curcumin loaded chitosan nanoparticles impregnated into collagenalginate scaffolds for diabetic wound healing. Int. J. Biol. Macromol. 2016, 93, 1519-1529. [CrossRef]

143. Carlson, L.J.; Cote, B.; Alani, A.W.; Rao, D.A. Polymeric micellar co-delivery of resveratrol and curcumin to mitigate in vitro doxorubicin-induced cardiotoxicity. J. Pharm. Sci. 2014, 103, 2315-2322. [CrossRef]

144. Li, J.; Zhou, Y.; Zhang, W.; Bao, C.; Xie, Z. Relief of oxidative stress and cardiomyocyte apoptosis by using curcumin nanoparticles. Colloids Surf. B Biointerfaces 2017, 153, 174-182. [CrossRef]

145. Zhang, J.; Wang, Y.; Bao, C.; Liu, T.; Li, S.; Huang, J.; Wan, Y.; Li, J. Curcumin-loaded PEG-PDLLA nanoparticles for attenuating palmitate-induced oxidative stress and cardiomyocyte apoptosis through AMPK pathway. Int. J. Mol. Med. 2019, 44, 672-682. [CrossRef] [PubMed]

146. Nabofa, W.E.E.; Alashe, O.O.; Oyeyemi, O.T.; Attah, A.F.; Oyagbemi, A.A.; Omobowale, T.O.; Adedapo, A.A.; Alada, A.R.A. Cardioprotective Effects of Curcumin-Nisin Based Poly Lactic Acid Nanoparticle on Myocardial Infarction in Guinea Pigs. Sci. Rep. 2018, 8, 16649. [CrossRef]

147. Ray, A.; Rana, S.; Banerjee, D.; Mitra, A.; Datta, R.; Naskar, S.; Sarkar, S. Improved bioavailability of targeted Curcumin delivery efficiently regressed cardiac hypertrophy by modulating apoptotic load within cardiac microenvironment. Toxicol. Appl. Pharmacol. 2016, 290, 54-65. [CrossRef] [PubMed]

148. Jazayeri-Tehrani, S.A.; Rezayat, S.M.; Mansouri, S.; Qorbani, M.; Alavian, S.M.; Daneshi-Maskooni, M.; Hosseinzadeh-Attar, M.J. Nano-curcumin improves glucose indices, lipids, inflammation, and Nesfatin in overweight and obese patients with non-alcoholic fatty liver disease (NAFLD): A double-blind randomized placebo-controlled clinical trial. Nutr. Metab. (Lond.) 2019, 16, 8. [CrossRef] [PubMed]

149. Chai, S.C.; Davis, K.; Wright, R.S.; Kuczmarski, M.F.; Zhang, Z. Impact of tart cherry juice on systolic blood pressure and low-density lipoprotein cholesterol in older adults: A randomized controlled trial. Food Funct. 2018, 9, 3185-3194. [CrossRef] [PubMed]

150. Kelley, D.S.; Adkins, Y.; Laugero, K.D. A review of the health benefits of cherries. Nutrients 2018, 10, 368. [CrossRef] [PubMed]

151. Jakobek, L.; Šeruga, M.; Voća, S.; Šindrak, Z.; Dobričević, N. Flavonol and phenolic acid composition of sweet cherries (cv. Lapins) produced on six different vegetative rootstocks. Sci. Horticult. 2009, 123, $23-28$. [CrossRef]

152. Beconcini, D.; Felice, F.; Fabiano, A.; Sarmento, B.; Zambito, Y.; Di Stefano, R. Antioxidant and anti-inflammatory properties of cherry extract: Nanosystems-based strategies to improve endothelial function and intestinal absorption. Foods 2020, 9, 207. [CrossRef] [PubMed]

153. Seeram, N.P.; Momin, R.A.; Nair, M.G.; Bourquin, L.D. Cyclooxygenase inhibitory and antioxidant cyanidin glycosides in cherries and berries. Phytomedicine 2001, 8, 362-369. [CrossRef] [PubMed]

154. Xu, J.W.; Ikeda, K.; Yamon, Y. Upregulation of endothelial nitric oxide synthase by cyanidin-3-glucoside, a typical anthocyanin pigment. Hypertension 2004, 44, 217-222. [CrossRef] [PubMed] 
155. Saric, A.; Sobacanec, S.; Balog, T.; Kusic, B.; Sverko, V.; Dragovic-Uzelac, V.; Levaj, B.; Cosic, Z.; Safranko, Z.M.; Marotti, T. Improved antioxidant and anti-inflammatory potential in mice consuming sour cherry juice (Prunus cerasus cv. Maraska). Plant Foods Hum. Nutr. 2009, 64, 231-237. [CrossRef] [PubMed]

156. Dayar, E.; Cebova, M.; Lietava, J.; Panghyova, E.; Pechanova, O. Beneficial Effects of Cornelian Cherries on Lipid Profile and NO/ROS Balance in Obese Zucker Rats: Comparison with CoQ10. Molecules 2020, 25, 1922. [CrossRef] [PubMed]

157. Chai, S.C.; Davis, K.; Zhang, Z.; Zha, L.; Kirschner, K.F. Effects of tart cherry juice on biomarkers of inflammation and oxidative stress in older adults. Nutrients 2019, 11, 228. [CrossRef]

158. Munin, A.; Edwards-Lévy, F. Encapsulation of natural polyphenolic compounds: A review. Pharmaceutics 2011, 3, 793-829. [CrossRef]

159. Beconcini, D.; Fabiano, A.; Zambito, Y.; Berni, R.; Santoni, T.; Piras, A.M.; Di Stefano, R. Chitosan-based nanoparticles containing cherry extract from Prunus avium L. to improve the resistance of endothelial cells to oxidative stress. Nutrients 2018, 10, 1598. [CrossRef]

160. Beconcini, D.; Fabiano, A.; Di Stefano, R.; Macedo, M.H.; Felice, F.; Zambito, Y.; Sarmento, B. Cherry Extract from Prunus avium L. to improve the resistance of endothelial cells to oxidative stress: Mucoadhesive chitosan vs. poly (lactic-co-glycolic acid) nanoparticles. Int. J. Mol. Sci. 2019, 20, 1759. [CrossRef]

161. Ma, Y.; Fu, L.; Hussain, Z.; Huang, D.; Zhu, S. Enhancement of storability and antioxidant systems of sweet cherry fruit by nitric oxide-releasing chitosan nanoparticles (GSNO-CS NPs). Food Chem. 2019, 285, 10-21. [CrossRef] [PubMed]

(C) 2020 by the authors. Licensee MDPI, Basel, Switzerland. This article is an open access article distributed under the terms and conditions of the Creative Commons Attribution (CC BY) license (http://creativecommons.org/licenses/by/4.0/). 